\title{
Protective effect of selenium against aluminium chloride induced cardiotoxicity in rats
}

\author{
Imen Ghorbel $^{1 *}$, Awatef Elwej ${ }^{1 \#,}$ Mariem Chaabane ${ }^{1 \#}$, Kamel Jamoussi ${ }^{2}$, Najiba Zeghal ${ }^{1}$ \\ ${ }^{1}$ Animal Physiology Laboratory. Sciences Faculty of Sfax. University of Sfax, BP 1171, 3000 Sfax, Tunisia \\ ${ }^{2}$ Biochemistry Laboratory, CHU Hedi Chaker, University of Sfax, 3029 Sfax, Tunisia
}

\begin{abstract}
Our study pertains to evaluate the protective effect of selenium (Se), used as a nutritional supplement, against aluminium chloride induced cardiotoxicity in rats. Rats have received during 21 days either $\mathrm{AlCl}_{3}(400 \mathrm{ppm})$ via drinking water, $\mathrm{AlCl}_{3}$ associated with $\mathrm{Na}_{2} \mathrm{SeO}_{3}\left(0.5 \mathrm{mg} / \mathrm{kg}\right.$ of diet) or only $\mathrm{Na}_{2} \mathrm{SeO}_{3}$. Co-administration of $\mathrm{Se}$ to $\mathrm{AlCl}_{3}$ treated rats alleviated heart oxidative stress objectified by a decrease of malondialdehyde, hydrogen peroxide and protein carbonyls levels. An improvement in antioxidant redox status, enzymatic (catalase, superoxide dismutase and glutathione peroxidase) and non enzymatic (reduced glutathione, non protein thiols and vitamin C) was also observed in Se treated rats. LDH and CK activities, TC, LDL-C levels, TC/HDL-C and LDL-C/HDL-C ratios were increased, while HDL-C and TG decreased in rats treated with $\mathrm{AlCl}_{3}$. Cardiac biomarkers and lipid profile were restored to near control values by the supplementation of Se. Our results revealed that $\mathrm{Se}$, a trace element with antioxidant properties, was effective in preventing heart damage induced by aluminium chloride.
\end{abstract}

Keywords: Aluminium, rats, oxidative stress, selenium, heart

Pharm Biomed Res 2017; 3(2): 19-25

\section{Introduction}

Aluminium ( $\mathrm{Al})$ is broadly dispersed throughout the natural and industrial environment (1). It is widely used in daily life causing its easy exposure to animals and human beings. Al sources are mainly corn, yellow cheese, salt, herbs, spices, tea, cosmetics, ware, and containers. It has been reported that $\mathrm{Al}$ could accumulate in all tissues of animals, preferentially in liver, heart, bones and brain (2). This metal disrupts the prooxidant/antioxidant balance in tissues leading to biochemical and physiological dysfunction due to an excessive reactive oxygen species (ROS) generation $(3,4)$. Chronic aluminium exposure results in a decreased activity of complexes I, II and IV of electron transport chain leading to the impairment of mitochondrial energy metabolism and oxidative damage (5). Oxidative stress may play a crucial role in cardiac and vascular abnormalities in different types of cardiovascular diseases (6). The mechanism by which $\mathrm{Al}$ produces cardiotoxicity effects may be attributed to oxidative stress and disturbance of the intracellular redox system.Supplementation of antioxidants can be considered as an alternative method to alleviate metals induced oxidative heart damage. Selenium (Se) is generally recognized to be a trace element of great importance for human health which protects the cells from the harmful effects of free radicals attack (7). Previous studies have confirmed the protective effects of Se against free-radical induced cardiac injury $(8,9)$. It plays an important role in many physiological processes including the biosynthesis of coenzyme Q, regulation of ion fluxes across membranes and stimulation of immune function (10). The beneficial effect of Se is attributed to selenoproteins such as glutathione peroxidase and thioredoxin reductase.

The underlying mechanisms of Al-induced toxicity are not entirely clear; however, they are apparently related to its pro-oxidant effects. To our knowledge, findings concerning the cardiotoxic effects of $\mathrm{Al}$ remain scarce and appear to be lacking. In an effort to better our understanding on aluminum heart toxicity mechanism, the present study was designed to explore whether the administration of this metal induced heart tissue damage in adult rats and to evaluate the possible ameliorative effect of Se.

\section{Materials and methods}

Chemicals

Aluminium Chloride (AlCl3), selenium $\left(\mathrm{Na}_{2} \mathrm{SeO}_{3}\right)$, glutathione (oxidized and reduced), 
nicotinamide adenine dinucleotide phosphate reduced form (NADPH), 5, 5'-dithiobis-2nitrobenzoic acid (DTNB) and thiobarbituric acid (TBA) were purchased from Sigma (St. Louis; MO,USA). All other chemicals, of analytical grade, were purchased from standard commercial suppliers.

\section{Animals and treatment}

Female Wistar rats, weighing $160 \pm 10 \mathrm{~g}$, were obtained from the Central Pharmacy (SIPHAT, Tunisia). They were housed at ambient temperature (22 $\pm 2{ }^{\circ} \mathrm{C}$ ) in a 12-h light/dark cycle and a minimum relative humidity of $40 \%$. Food (SNA, Sfax, Tunisia) and water were available ad libitum. One week after acclimatization to laboratory conditions, the rats were randomly divided into four groups of six each. Animals were treated for a period of 21 days as follows: group I, serving as negative control, received standard diet and distilled water; group II received via drinking water $\mathrm{AlCl}_{3}\left(50 \mathrm{mg} / \mathrm{kg}\right.$ bw); group III received both $\mathrm{AlCl}_{3}$ and $\mathrm{Se}(0.5 \mathrm{mg} / \mathrm{Kg}$ of diet) and group IV, serving as a positive control, received $\mathrm{Se}$ as sodium selenite $\left(\mathrm{Na}_{2} \mathrm{SeO}_{3}\right)$ at a dose of $0.5 \mathrm{mg} / \mathrm{kg}$ of diet. The dose of selenium $(0.5 \mathrm{mg} / \mathrm{kg}$ of diet $)$ used in our study and in other findings gave high protection against stress conditions in several tissues $(11,12)$. The dose of aluminium chloride (50 mg/kg bw) used in our experiment, which corresponded to $1 / 8$ of LD50 was chosen according to Allagui et al. (13). At the end of the experimental period, animals were killed by cervical decapitation to avoid stress. Blood was collected into heparinized tubes and centrifuged at $2200 \times$ g for $10 \mathrm{~min}$. Plasma samples were drawn and stored at $-80^{\circ} \mathrm{C}$ until analysis. Hearts were dissected out, cleaned, homogenized in a Tris- $\mathrm{HCl}$ buffer $(\mathrm{pH}=$ 7.4) and centrifuged. The resulting supernatants were kept at $-80{ }^{\circ} \mathrm{C}$ for biochemical assays. Approval for rat experiments was obtained from the ethical Committee at Sciences Faculty of Sfax with ethics approval number 1204 and all the experimental procedures were in accordance with the International Guidelines for Animal Care (14).

\section{Biochemicals assays}

\section{Protein quantification}

Heart protein contents were measured according to the method of Lowry et al (15) using bovine serum albumin as standard.

\section{Heart malondialdehyde (MDA) measurement}

The extent of lipid peroxidation by measuring thiobarbituric acid reactive substances (TBARS) in terms of malondialdehyde (MDA) formation was measured according to the method of Draper and Hadley (16). The malondialdehyde values were calculated using 1, 1, 3, 3-tetraethoxypropane as standard and expressed as nmoles of MDA /mg protein.

\section{Hydrogen peroxide $\left(\mathrm{H}_{2} \mathrm{O}_{2}\right)$ measurement}

Measurement of hydrogen peroxide $\left(\mathrm{H}_{2} \mathrm{O}_{2}\right)$ was carried out according to $\mathrm{Ou}$ and Woff (17) method. The amount of $\mathrm{H}_{2} \mathrm{O}_{2}$

produced was determined using the extinction coefficient of $2.67 \times 10^{5} \mathrm{~cm}^{-1} \mathrm{M}^{-1}$ and results were expressed as nmoles/mg protein.

\section{Heart PCO levels}

Protein carbonyls (PCO) were measured using the method of Reznick and Packer (18). The carbonyl content was calculated based on the molar extinction coefficient of DNPH $\left(£=2.2 * 10^{4} \mathrm{~cm}^{-1} \mathrm{M}^{-1}\right)$ and expressed as nmoles/mg protein.

\section{GSH, NPSH and vitamin C levels}

GSH levels in the heart were determined by the method of Ellman (19) modified by Jollow et al (20). Total GSH content in the heart was expressed as $\mu \mathrm{g} / \mathrm{mg}$ of protein. Non protein thiol (NPSH) levels were determined by the method of Ellman (19). The total NPSH content was expressed as nmol/ $\mathrm{mg}$ of protein.

Ascorbic acid determination was performed as described by Jacques-Silva et al (21). The data were expressed as $\mu$ moles of ascorbic acid/mg of protein.

\section{Heart enzymatic antioxidant activities}

Catalase (CAT) activity was determined by the method of Aebi (22) using hydrogen peroxide $\left(\mathrm{H}_{2} \mathrm{O}_{2}\right)$ as substrate. A decrease in absorbance due to $\mathrm{H}_{2} \mathrm{O}_{2}$ degradation was monitored spectrophotometrically at $240 \mathrm{~nm}$ for $1 \mathrm{~min}$ and the enzyme activity was expressed as $\mu$ moles $\mathrm{H}_{2} \mathrm{O}_{2}$ degraded/ $\mathrm{min} / \mathrm{mg}$ protein.

Glutathione peroxidase (GPx) activity was measured according to Flohe and Gunzler (23). The enzyme activity was expressed as nmoles of GSH oxidized/ $\mathrm{min} / \mathrm{mg}$ protein Superoxide dismutase (SOD) activity was estimated according to Beauchamp and Fridovich (24). 
Its optical density was measured at 560nm. Units of SOD activity were expressed as the amount of enzyme required to inhibit the reduction of NBT by $50 \%$ and the activity was expressed as Units /mg of protein.

\section{Plasma lipid profile}

Triglycerides, total cholesterol and HDL-Cholesterol levels in plasma were determined using kits from Biomaghreb (Tunisia, 20131, 20111, 20113) respectively. The LDL-Cholesterol fraction and atherogenic index (AI) were determined according to the Friedewald equations (25).

[LDL-Cholesterol $]=$ Total cholesterol $-[$ Triglyceride 15) + HDL-Cholesterol]

$\mathrm{AI}=(\mathrm{TC}-\mathrm{HDL}-\mathrm{C}) / \mathrm{HDL}-\mathrm{C}$

TC/HDL-C and LDL-C/HDL-C ratios were also calculated.

\section{Biomarkers of cardiotoxicity}

Plasma and heart Lactate dehydrogenase (LDH) and plasma creatine kinase isoenzyme (CK-MB) activities were determined according to standard methods by using diagnostic kits from Biomaghreb (Tunisia, Ref 20012, 20049 and 20063 respectively).

\section{Statistical analysis}

The data were analyzed using the statistical package program Stat view 5 Software for Windows (SAS Institute, Berkley, CA). Statistical analysis was performed using one-way analysis of variance (ANOVA) followed by Fisher's protected least significant difference (PLSD) test as a post hoc test for comparison between groups. Student unpaired t-test was also used when comparison between two groups was required. All values were expressed as means \pm S.D. The 0.05 level was selected as the point of minimal statistical significance.

\section{Results}

Estimation of MDA, $\mathrm{PCO}$ and $\mathrm{H}_{2} \mathrm{O}_{2}$ levels

A significant increase in $\mathrm{MDA}(+69 \%), \mathrm{H}_{2} \mathrm{O}_{2}(+85 \%)$ and PCO $(+36 \%)$ levels was observed in the heart of $\mathrm{AlCl}_{3}$ treated rats (Table 1). Co-administration of selenium via diet restored these parameters to near control values $(\mathrm{p}<0.001)$.

\section{GSH, NPSH and vitamin C levels}

A significant decrease of GSH, NPSH and vitamin C levels $\left(17,34\right.$ and 22\%) in the cardiac tissue of $\mathrm{AlCl}_{3}$ group was observed when compared to those of controls. These modifications were significantly improved after co-administration of Se which reached control values (Table 2).

\section{Heart enzymatic antioxidant status}

Antioxidant enzyme activities of CAT, GPx and SOD of control and treated groups are represented in Figure 1 .

Table $1 \mathrm{MDA}, \mathrm{H}_{2} \mathrm{O}_{2}$ and PCO levels in the heart of control and treated rats with $\mathrm{AlCl}_{3}$, Se or their combination $\left(\mathrm{AlCl}_{3}+\mathrm{Se}\right)$.

\begin{tabular}{ccccc}
\hline & Controls & $\mathbf{A l C l}_{3}$ & $\mathbf{A l C l}_{3}+\mathbf{S e}$ & $\mathbf{S e}$ \\
\hline $\mathbf{M D A}^{\mathrm{a}}$ & $1.37 \pm 0.21$ & $2.32 \pm 0.11^{* * * *}$ & $1.21 \pm 0.07^{+++}$ & $1.31 \pm 0.08$ \\
$\mathbf{H}_{2} \mathbf{O}_{2}{ }^{\mathrm{b}}$ & $20.44 \pm 1.63$ & $37.82 \pm 2.37^{* * * *}$ & $20.83 \pm 0.73^{++}$ & $19.91 \pm 0.65$ \\
$\mathbf{P C O}^{\mathrm{b}}$ & $0.91 \pm 0.04$ & $1.24 \pm 0.05^{\text {********}}$ & $0.98 \pm 0.06^{*++}$ & $0.89 \pm 0.03$ \\
\hline
\end{tabular}

\footnotetext{
${ }^{\mathrm{a}} \mathrm{nmol}$ of $\mathrm{MDA} / \mathrm{mg}$ protein

${ }^{\mathrm{b}} \mathrm{nmol} / \mathrm{mg}$ protein

Values were expressed as means $\pm \mathrm{SD}$

$\mathrm{AlCl}_{3},\left(\mathrm{AlCl}_{3}+\mathrm{Se}\right)$ and $\mathrm{Se}$ groups vs control group: ${ }^{*} \mathrm{P}<0.05$;

${ }^{* *} \mathrm{P}<0.001$.

$\left(\mathrm{AlCl}_{3}+\mathrm{Se}\right)$ vs $\mathrm{AlCl}_{3}:{ }^{+++} \mathrm{P}<0.001$.
}

Table 2 Non enzymatic antioxidant levels (GSH, NPSH and vitamin $\mathrm{C}$ ) in the heart of control and treated rats with $\mathrm{AlCl}_{3}$, Se or their combination $\left(\mathrm{AlCl}_{3}+\mathrm{Se}\right)$.

\begin{tabular}{|c|c|c|c|c|}
\hline & Control & $\mathrm{AlCl}_{3}$ & $\mathrm{AlCl}_{3}+\mathrm{Se}$ & Se \\
\hline GSH $^{a}$ & $5.59 \pm 0.12$ & $4.62 \pm 0.31^{* * *}$ & $5.49 \pm 0.36^{+++}$ & $5.62 \pm 0.29$ \\
\hline NPSH $^{b}$ & $22.22 \pm 1.33$ & $14.54 \pm 0.97^{* * *}$ & $21.13 \pm 0.99$ & $21.11 \pm 0.89$ \\
\hline Vitamin $C^{c}$ & $1.52 \pm 0.04$ & $1.19 \pm 0.03^{* * * *}$ & $1.50 \pm 0.06$ & $1.53 \pm 0.05$ \\
\hline \multicolumn{5}{|c|}{$\begin{array}{l}\text { a } \mu \mathrm{g} / \mathrm{mg} \text { protein } \\
{ }^{\mathrm{b}} \mathrm{nmol} / \mathrm{mg} \text { protein }\end{array}$} \\
\hline \multicolumn{5}{|c|}{$\begin{array}{l}\text { c } \mu \mathrm{mol} / \mathrm{mg} \text { protein } \\
\text { Values were expressed as means } \pm \mathrm{SD} \text {. }\end{array}$} \\
\hline
\end{tabular}

$\mathrm{AlCl}_{3}$ treatment resulted in a significant decrease $(\mathrm{P}<$ 0.001 ) in the activities of these enzymes by 47,42 and $49 \%$ when compared to those of control group. Treatment with Se improved the activities of antioxidant enzymes without reaching control values $(\mathrm{p}<0.001)$. 

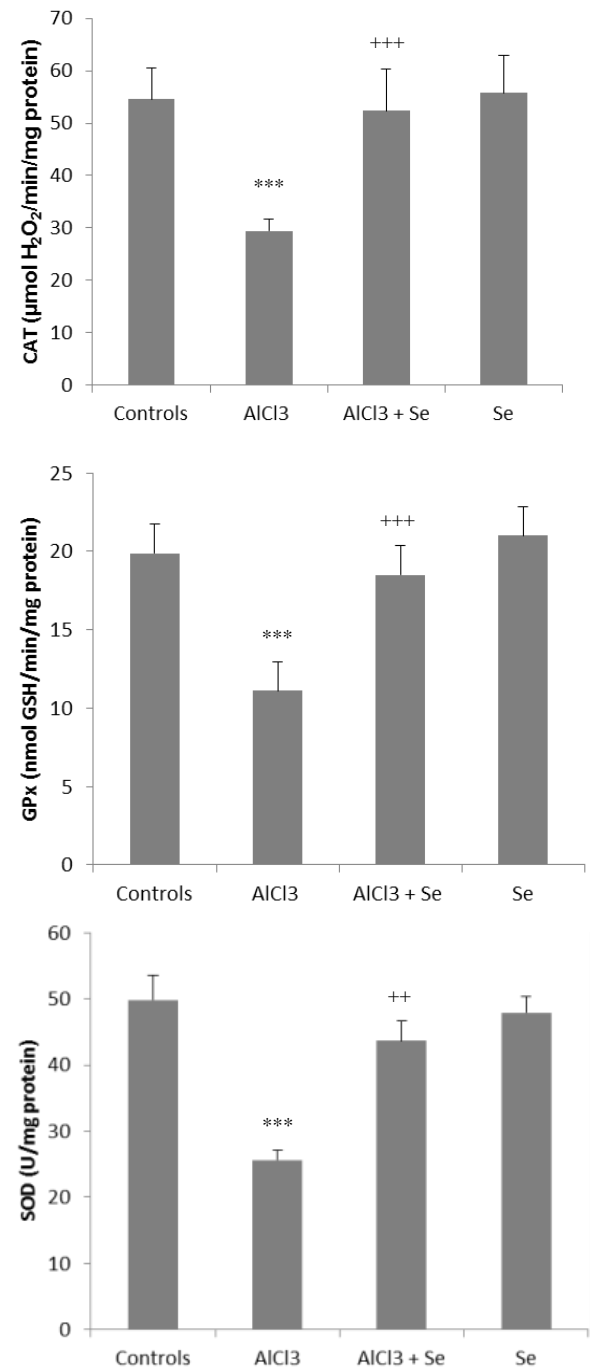

Figure 1 Antioxidant enzyme activities (CAT, GPx and $\mathrm{SOD}$ ) in the heart of control and treated rats with $\mathrm{AlCl}_{3}, \mathrm{Se}$ and their combination $\left(\mathrm{AlCl}_{3}+\mathrm{Se}\right)$.

Values are means $\pm \mathrm{SD}$ for six rats in each group.

$\mathrm{AlCl}_{3},\left(\mathrm{AlCl}_{3}+\mathrm{Se}\right)$ and $\mathrm{Se}$ treated groups vs. control group: $* * * \mathrm{p}<0.001$.

$\left(\mathrm{AlCl}_{3}+\mathrm{Se}\right.$ ) group vs. $\mathrm{AlCl}_{3}$ group: $+\mathrm{p}<0.01 ;++\mathrm{p}<0.001$.

\section{Biomarkers of cardiotoxicity}

$\mathrm{LDH}$ activity in $\mathrm{AlCl}_{3}$ group was decreased in the heart by $45 \%$ while it increased in plasma by $70 \%$, when compared to those of controls indicating the occurrence of heart injury (Figure 2). A significant increase in the activity of plasma CK was also observed following aluminium treatment. Co-administration of $\mathrm{Se}$ in the diet restored the values of $\mathrm{LDH}$ and $\mathrm{CK}$ activities (Figure 2).

\section{Effects of $\mathrm{AlCl}_{3}$ on lipid profile}

In $\mathrm{AlCl}_{3}$ treated rats, there was an increase in the levels of TG (11\%), TC (20\%) and LDL-C (23\%) and a decrease in TG (13\%) and HDL-C (41\%) levels.
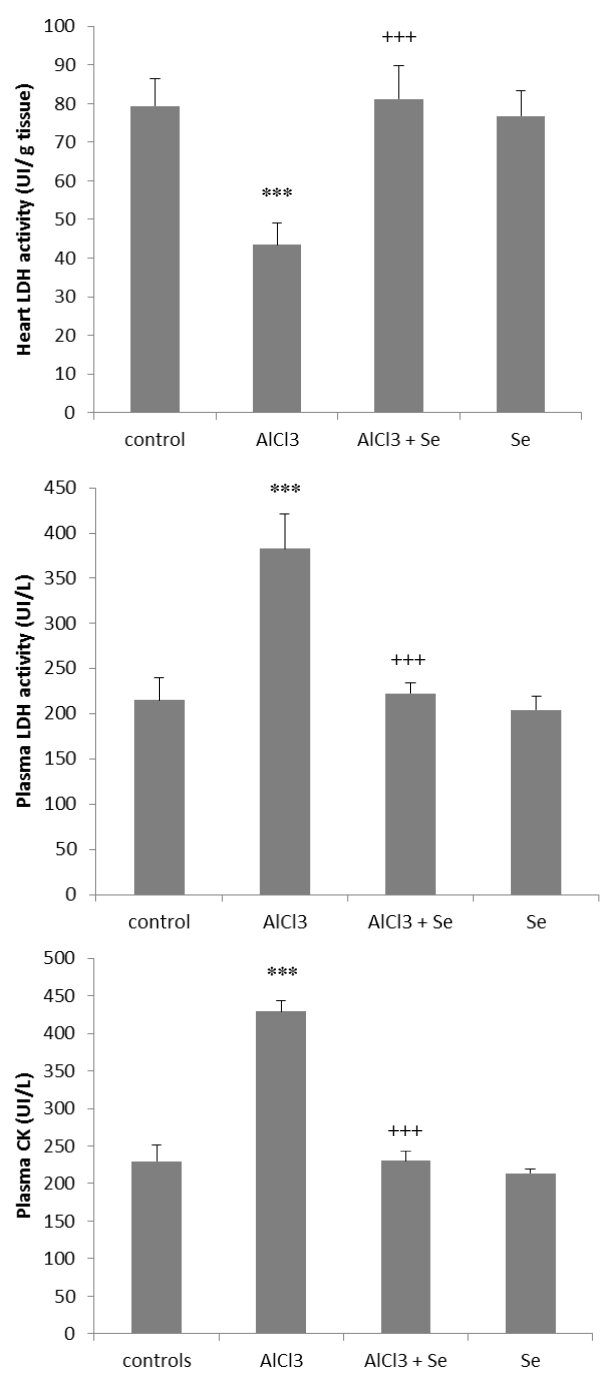

Figure 2 Cardiac markers (LDH and CK) in plasma and heart of control and treated rats with $\mathrm{AlCl}_{3}, \mathrm{Se}$ and their combination $\left(\mathrm{AlCl}_{3}+\mathrm{Se}\right)$.

Values are means $\pm \mathrm{SD}$ for six rats in each group.

$\mathrm{AlCl}_{3},\left(\mathrm{AlCl}_{3}+\mathrm{Se}\right)$ and $\mathrm{Se}$ treated groups vs. control group: $* * *$ $\mathrm{p}<0.001$.

$\left(\mathrm{AlCl}_{3}+\mathrm{Se}\right)$ group vs. $\mathrm{AlCl}_{3}$ group: $++\mathrm{p}<0.001$.

TC/HDL-C and LDL-C/HDL-C ratios and AI were increased by 93,105 and $135 \%$ respectively when compared to controls (Table 3). Supplementation of Se in the diet of $\mathrm{AlCl}_{3}$ treated rats improved the parameters cited above.

\section{Discussion}

The mitochondrion is the primary intracellular sites of oxygen consumption, whose function is closely linked to the maintenance of redox balance. An imbalance between the overproduction of reactive oxygen species (ROS) and elimination of free radicals induces oxidative stress. 
Aluminium toxicity involves oxidative damage playing an imperative role in biochemical alterations. In the present study, exposure of rats to $\mathrm{Al}$ through drinking water resulted in a significant increase in lipid and protein oxidation in the heart tissue as evidenced by the significant increase in MDA and PCO levels. According to Nehru and Anand (26), the increase in free intracellular $\mathrm{Fe}^{2+}$ causes the peroxidation of lipids and membrane damages in aluminum-treated rats. Lipid peroxidation and production of ROS are the main molecular mechanisms of Al-induced cell damage (27, 28). ROS, including $\mathrm{H}_{2} \mathrm{O}_{2}$, generated probably by $\mathrm{Al}$ treatment induced a rise of hydrogen peroxide $\left(\mathrm{H}_{2} \mathrm{O}_{2}\right)$ levels suggesting the dysfunction of the mitochondrial respiration chain. The increase of these parameters was well mitigated close to normal levels by the supplementation of selenium. It has been reported to be a protector against lipid peroxidation and useful in the management of myocardial injury (29).

As a consequence of lipid peroxidation, biological membranes are affected leading to the loss of their fluidity and an increase of their permeability leading to the leakage of enzymes. In this regard, lactate dehydrogenase $(\mathrm{LDH})$ and creatine kinase $(\mathrm{CK})$ are considered as the reliable markers of cardiac damage. Several studies have consistently reported the elevated activities of these enzymes in the serum of experimental animals immediately after myocardial infarction (30) Our results showed that CK and LDH activities in the plasma of $\mathrm{Al}$ treated rats were clearly increased while $\mathrm{LDH}$ decreased in the cardiac tissue confirming the loss of membrane permeability and myocardial injury. Selenium prevented the leakage of $\mathrm{LDH}$ and $\mathrm{CK}$ from the heart to the extracellular compartment due to its powerfull antioxidant potential ensuring the stabilization of membrane.

An antioxidant defense system, mainly involved in scavenging ROS prevents oxidative stress. Antioxidant enzymes, like SOD, CAT and GPx, are recognized as the primary cellular defense against free radicalmediated oxidative stress. In the current study, the homeostasis of antioxidant defenses was altered, as shown by a significant decrease in the activities of these enzymes. Our results were in accordance with the previous reports of Azad et al (31) who have shown an increase in myocardial malonyldialdehyde level and a decrease in antioxidant enzyme activities after aluminium phosphide treatment. When oxidative stress is in excess, the non-enzymatic antioxidant system like
Table 3 Lipid profile in plasma of control and treated rats with $\mathrm{AlCl}_{3}$, selenium $(\mathrm{Se})$ or their combination $\left(\mathrm{AlCl}_{3}+\mathrm{Se}\right)$

\begin{tabular}{|c|c|c|c|c|}
\hline $\begin{array}{l}\text { Parameters } \\
\text { and } \\
\text { treatments }\end{array}$ & Controls & $\mathbf{A l C l}_{3}$ & $\mathrm{AlCl}_{3}+\mathrm{Se}$ & $\mathrm{Se}$ \\
\hline Triglycerides ${ }^{\text {a }}$ & $70.29 \pm 6.34$ & $78.3 \pm 5.73^{*}$ & $73.95 \pm 2.62$ & $72.42 \pm 2.4$ \\
\hline $\begin{array}{l}\text { Total } \\
\text { cholesterol a }\end{array}$ & $62 \pm 3.08$ & $74.3 \pm 3.07^{* * * k}$ & $66.02 \pm 5.01^{++}$ & $65.30 \pm 5.81$ \\
\hline $\begin{array}{l}\text { HDL- } \\
\text { Cholesterol a }\end{array}$ & $19.03 \pm 2.13$ & $11.42 \pm 1.77^{\text {*ate }}$ & $15.78 \pm 2.09^{*++}$ & $17.41 \pm 1.06$ \\
\hline $\begin{array}{l}\text { LDL- } \\
\text { cholesterol a }^{\text {a }}\end{array}$ & $26.38 \pm 2.34$ & $32.25 \pm 1.05^{\text {* }}$ & $28.26 \pm 2.11^{+++}$ & $28.25 \pm 2.25$ \\
\hline $\begin{array}{l}\text { Atherogenix } \\
\text { Index (AI) }\end{array}$ & $2.26 \pm 0.24$ & $5.32 \pm 0.88^{* * * k}$ & $3.22 \pm 0.52^{*+++}$ & $2.81 \pm 0.41$ \\
\hline TC/HDL-C ${ }^{a}$ & $3.26 \pm 0.26$ & $6.32 \pm 0.88^{\text {**⿲二丨匕日 }}$ & $4.22 \pm 0.52^{* *++}$ & $3.81 \pm 0.41^{*}$ \\
\hline $\begin{array}{l}\text { LDL-C/ HDL- } \\
C^{\text {a }}\end{array}$ & $1.40 \pm 0.18$ & $2.87 \pm 0.39^{\text {*Nak }}$ & $1.97 \pm 0.35^{++}$ & $1.62 \pm 0.22$ \\
\hline
\end{tabular}

HDL-C: high density lipoprotein-cholesterol; LDL-C: low density lipoprotein-cholesterol

${ }^{\mathrm{a}} \mathrm{mg} / \mathrm{dl}$

Values were expressed as means $\pm \mathrm{SD}$

$\mathrm{AlCl}_{3},\left(\mathrm{AlCl}_{3}+\mathrm{Se}\right)$ and $\mathrm{Se}$ groups vs control group: $* \mathrm{P}<0.05 ; * * \mathrm{P}<0.01$; $* * * \mathrm{P}<0.001$

$\left(\mathrm{AlCl}_{3}+\mathrm{Se}\right)$ vs $\mathrm{AlCl}_{3}:{ }^{++} \mathrm{P}<0.01 ;{ }^{+++} \mathrm{P}<0.001$

GSH, NPSH and vitamin C complements the activity of the enzymatic antioxidant system. Thiol based antioxidant system plays a second line of cellular defense against free radicals and other oxidant species mediated oxidative damage. In the present study following aluminium treatment, cardiac glutathione redox status was greatly impaired, as indicated by a significant decrease in the levels of GSH and NPSH. Because GSH is involved in recycling vitamin $\mathrm{C}$ by mediating the reduction of dehydroascorbate, (32) the GSH deficiency would be expected to reduce the vitamin $\mathrm{C}$ levels in the heart of treated rats. Treatment with selenium could react against $\mathrm{Al}$ induced oxidative stress in the heart, due to its anti-oxidative potential.

Oxidative stress induced by $\mathrm{Al}$ caused disturbances in cellular functions and induced a defect in the synthesis and secretion of lipoproteins of the heart. Lipids are thought to be among the most sensitive biological molecules in terms of ROS susceptibility. The increase in the level of total cholesterol in $\mathrm{Al}$ treated rats may be due to an increased cholesterol synthesis in the liver (33). Low density lipoprotein-cholesterol (LDL-C) increased, while high density lipoprotein-cholesterol (HDL-C) decreased, suggesting that the abnormal activities of lipase enzymes seem to be one of the chief factors responsible for the cholesterol rise in serum. Our data showed that exposure rats to $\mathrm{AlCl}_{3}$ increased significantly LDL-C/HDL-C and TC/HDL-C ratios, considered by Reaven et al (34) as the pertinent indices 
of cardiovascular risk incidence (atherosclerotic index). The supplementation of $\mathrm{Se}$ to $\mathrm{AlCl}_{3}$ treated rats restored the changes of lipid profile near control values. In fact, Se acts as an antioxidant and inhibits the oxidative processes of lipids and lipoproteins in cell membranes (35).

\section{Conclusion}

In the present study, oxidative stress induced by $\mathrm{Al}$ in the heart tissue of rats might be responsible for the disruption of antioxidant status, oxidation of lipids and proteins and disturbance of lipid profile. Coadministration of Se can mitigate the toxic effects of aluminium by restabilization of the cell membranes, decreasing the levels of cardiotoxicity biomarkers and improvement of the redox state. Our results reflected that Se could be used as an effective supplement in the appropriate management of $\mathrm{Al}$ toxicity.

\section{Acknowledgements}

This work was supported by the Ministry of Higher Education and Scientific Research in Tunisia (DGRST grants, LR 11/ ES-53 Sciences Faculty of Sfax). The authors are indebted to Mr Menaa Assili and Mr Chedli Tmar for their skilful technical assistance.

\section{Conflit of interest}

The authors declare that they have no competing interests to disclose.

\section{References}

1. Verstraeten SV, Aimo L, Oteiza PI. Aluminium and lead: molecular mechanisms of brain toxicity. Arch Toxicol 2008;82:789-802.

2. Gonzales MA, Bernal CA, Mahieu S, Carrillo MC. The interactions between the chronic exposure to Aluminum and liver regeneration on bile flow and organic anion transport in rats. Biol Trace Elem Res 2009;127:164-76.

3. Ghorbel I, Chaabane M, Elwej A, Boudawara O, Abdelhedi S, Jamoussi K, et al. Expression of metallothioneins I and II related to oxidative stress in the liver of aluminium-treated rats. Arch Physiol Biochem 2016;122:214-22.

4. Ghorbel I, Elwej A, Chaabane M, Jamoussi K, Mnif H, Boudawara T, et al. Selenium Alleviates Oxidative Stress and Lung Damage Induced by Aluminum Chloride in Adult Rats: Biochemical and Histological Approach. Biol Trace Elem Res 2017;176:181-91.

5. Kumar V, Bal A, Gill KD. Impairment of mitochondrial energy metabolism in different regions of rat brain following chronic exposure to aluminium. Brain Res 2008;1232:94-103

6. Haidara MA, Yassin HZ, Rateb M, Ammar H, Zorkani MA. Role of oxidative stress in development of cardiovascular complications in diabetes mellitus. Curr Vasc Pharmacol 2006;4:215-27.
7. El-Demerdash FM. Antioxidant effect of vitamin E and selenium on lipid peroxidation,enzyme activities and biochemical parameters in rats exposed to aluminium. J Trace Elem Med Biol 2004;18:113-21.

8. Danesi F, Malaguti M, Nunzio MD, Maranesi M, Biagi PL, Bordoni A. Counteraction of adriamycin-induced oxidative damage in rat heart by selenium dietary supplementation. J Agric Food Chem 2006;54:1203-8

9. Chaâbane M, Tir M, Hamdi S, Boudawara O, Jamoussi K, Boudawara T, et al. Improvement of Heart Redox States Contributes to the Beneficial Effects of Selenium Against Penconazole-Induced Cardiotoxicity in Adult Rats. Biol Trace Elem Res 2016;169:261-70.

10. Miller S, Walker SW, Arthur JR, Nicol F, Pickard K, Lewin $\mathrm{MH}$, et al. Selenite protects human endothelial cells from oxidative damage and induces thioredoxin reductase. Clin Sci 2001;100:543-50.

11. Ognjanovic BI, Markovic SD, Pavlovic SZ, Zikic RV, Stajn AS, Saicic ZS. Effect of chronic cadmium exposure on antioxidant defense system in some tissues of rats: protective effect of selenium. Physiol Res 2008;57:403-11.

12. Soudani N, Sefi M, Ben Amara I, Boudawara T, Zeghal N. Protective effects of selenium (Se) on chromium (VI) induced nephrotoxicity in adult rats. Ecotoxicol Environ Saf 2010;73:671-8

13. Allagui MS, Feriani A, Saoudi M, Badraoui R, Bouoni Z, Nciri R, et al. Effects of melatonin on aluminium induced neurobehavioral and neurochemical changes in aging rats. Food Chem Toxicol 2014;70:84-93.

14. Council of European Communities. Official Journal of the European Communities JO 86/609/CEE. 1986;358:1-18.

15. Lowry OH, Rosebrough NJ, Farr AL, Randall R J. Protein measuremernt with the Folin phenol reagent. J Biol Chem 1951;193:269-75.

16. Draper HH, Hadley M. Malondialdehyde determination as index of lipid peroxidation. Methods Enzymol 1990;186:421-31.

17. Ou P, Wolff SP. A discontinuous method for catalase determination at near physiological concentrations of $\mathrm{H}_{2} \mathrm{O}_{2}$ and its application to the study of $\mathrm{H}_{2} \mathrm{O}_{2}$ fluxes within cells. J Biochem Biophys Methods 1996;31:59-67.

18. Reznick Z, Packer L. Oxidative damage to proteins: spectrophotometric method for carbonyl. Method Enzymol 1994; 233:357-63.

19. Ellman GL. Tissue sulfhydryl groups. Arch Biochem Biophys 1959;82: 70-7.

20. Jollow DJ, Mitchell JR, Zampaglione N, Gillette JR. Bromobenzene-induced liver necrosis. Protective role of glutathione and evidence for 3, 4-bromobenzene oxide as the hepatotoxic metabolite. Pharmacol 1974;11:151-69.

21. Jacques-Silva MC, Nogueira CW, Broch LC, Flores EM, Rocha JB. Diphenyl diselenide and ascorbic acid changes deposition of selenium and ascorbic acid in liver and brain of mice. Pharm Toxicol 2001;88:119-25.

22. Aebi H. Catalase in vitro. Methods Enzymol 1984;105:121-6.

23. Flohe L, Gunzler WA. Assays of glutathione peroxidase. Methods Enzymol 1984;105:114-21.

24. Beauchamp C, Fridovich I. Superoxide dismutase: improved assays and an assay applicable to acrylamide gels. Anal Biochem 1971;44:276-87.

25. Friedewald WT, Levy RI, Fredrickson DS. Estimation of concentration of low-density lipoprotein cholesterol in plasma without use of the preparative ultracentrifuge. Clin Chem1972;18:499-502. 
26. Nehru B, Anand P. Oxidative damage following chronic aluminium exposure in adult and pup rat brains. J Trace Elem Med Biol 2005;19:203-8.

27. Newairy AS, Salama AF, Hussien HM, Yousef MI Propolis alleviates aluminum- induced lipid peroxidation and biochemical parameters in male rats. Food Chem Toxicol 2009;47:1093-8

28. Yousef MI, Salama AF. Propolis protection from reproductive toxicity caused by aluminum chloride in male rats. Food Chem Toxicol 2009;47:116875

29. Gan L, Liu Q, Xu HB, Zhu YS, Yang XL. Effects of selenium overexposure on glutathione peroxidase and thioredoxin reductase gene expressions and activities. Biol Trace Elem Res 2002;89:165-75

30. Rajadurai M, Stanely Mainzen P. Preventive effect of naringin on cardiac markers, electrocardiographic patterns and lysosomal hydrolases in normal and isoproterenol-induced myocardial infarction in Wistar rats. Toxicol 2007;230:178-88
31. Azad A, Lall SB, Mittra S. Effect of N-acetylcysteine and L-NAME on aluminium phosphide induced cardiovascular toxicity in rats. Acta Pharmacol Sin 2001;22:298-304.

32. Rivers JM. Safety of high-level vitamin C ingestion. Int J Vitam Nutr Res Suppl 1989;30:95-102.

33. Kalender S, Ogutcu A, Uzunhisarcikli M, Acikgoz F, Durak D, Ulusoy Y, et al. Diazinon-induced hepatotoxicity and protective effect of vitamin $\mathrm{E}$ on some biochemical indices and ultra structural changes. Toxicol 2005;211:197-206.

34. Reaven GM. Importance of identifying the overnight patient who will benefit the most by losing weight. Ann Intern Med 2003;138:420-30.

35. McPherson A. Selenium vitamin E and biological oxidation. In: Cole DJ, Garnsworthy PJ, editors. Recent advances in animal nutrition. Oxford, Butterworth and Heinemann's; 1994. p. 3-30. 